\title{
Dryland crop production and greenhouse gas emissions in Canada: a regional comparison
}

\author{
S. Kulshreshtha ${ }^{1}$, J. Dyer ${ }^{2} \&$ B. McConkey ${ }^{3}$ \\ ${ }^{1}$ Department of Bioresource Policy, Business and Economics, \\ University of Saskatchewan, Canada \\ ${ }^{2}$ Agro-Environmental Consultant, Cambridge, Ontario, Canada \\ ${ }^{3}$ Soil and Water Conservationist, Agriculture and Agri-Food Canada \\ Environmental Health, Swift Current, Saskatchewan, Canada
}

\begin{abstract}
Agricultural production systems produce several environmental impacts, including emissions of greenhouse gases. The objective of this paper is to investigate differences in greenhouse gas emissions from various crops grown under dryland production system in various regions of Canada. Results indicate that the emissions intensity varies depending upon the measure adopted whether it is on per unit of area or production. In addition there is wide variability across regions of production. In the Prairie region, the greenhouse gas emissions intensity on a per hectare basis ranged from $378 \mathrm{~kg}$ for Alfalfa in Alberta to $1,837 \mathrm{~kg}$ for durum wheat in Saskatchewan. Generally, central Canada emits the highest GHG level on a per hectare basis but not on a tonne of production basis.
\end{abstract}

Keywords: crop production, greenhouse gas emissions, emission intensity, dryland production systems.

\section{Introduction}

\subsection{Background}

Greenhouse gas (GHG) emission reduction has been accepted by most countries as an important activity in helping to safeguard against future climate change. With this in mind, the international community has initiated measures to curb the rising trend in GHG emissions, and in fact, reduce them to a point where these 
are less harmful to society. Although compared to other industrial countries, Canada is not a major contributor of GHG emissions, with the 1990 total GHG emissions levels having represented just $1.8 \%$ of the global total, but on a percapita basis Canada ranks second-highest in emissions, exceeded only by the United States, Environment Canada [1]. Of the total GHG emissions of 734 megatonnes $(\mathrm{Mt})$ of carbon dioxide equivalent $\left(\mathrm{CO}_{2 \mathrm{e}}\right)$, the contribution of Canadian agriculture is only $8 \%$ of this total, Environment Canada [2]. This equivalency is calculated by converting methane $\left(\mathrm{CH}_{4}\right)$ by using its global warming potential of 21 , and nitrous oxide $\left(\mathrm{N}_{2} \mathrm{O}\right)$ of 310 times that of carbon dioxide $\left(\mathrm{CO}_{2}\right)$. Although the contribution level of $\mathrm{GHG}$ emissions from Canadian agriculture may be small in relation to other emission sources, as shown in figure 1, on an absolute scale, the total agricultural GHG emissions in 2008 were estimated to be $62 \mathrm{Mt}$ of $\mathrm{CO}_{2 \mathrm{e}}$ ). Agriculture is not a large contributor of $\mathrm{CO}_{2}$ but a large proportion of $\mathrm{CH}_{4}$ and $\mathrm{N}_{2} \mathrm{O}$ is emitted by agricultural production activities. In addition, agriculture contributed to total GHG emission indirectly through manufacturing of farm inputs, including off-farm transportation (Dyer and Desjardins [3]).

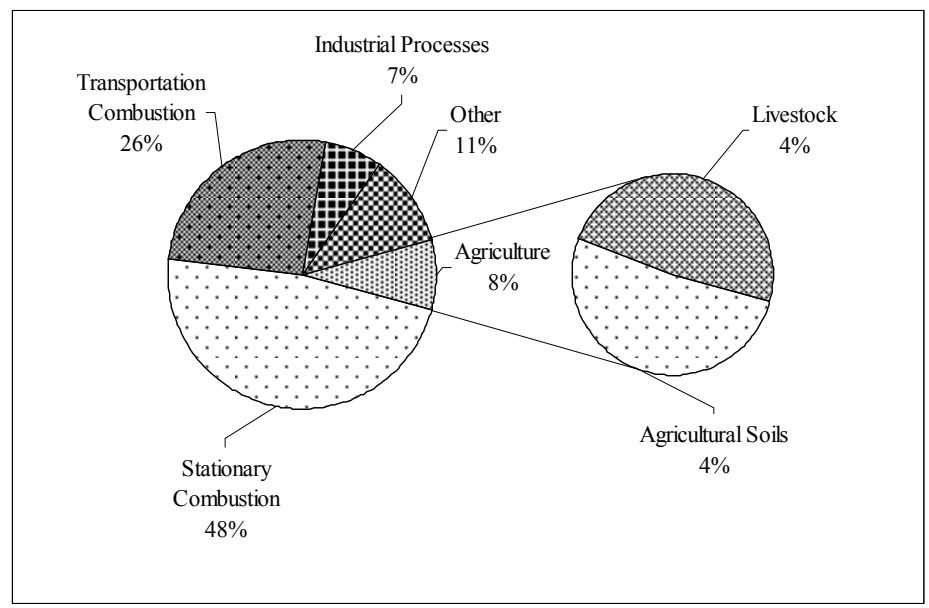

Figure 1: Distribution of greenhouse gas emissions in Canada by source, in $\mathrm{CO}_{2 \mathrm{e}}$.

\subsection{Need for the study}

Since the signing of the Kyoto Protocol by Canada and other countries, identification of GHG-emissions reduction potential of various sectors is an important activity. In this context, Canadian agriculture is viewed as playing a role in GHG emission mitigation as well as in sequestration. Crop production activities are major contributors to total Canadian agriculture GHG emissions. However, in order to develop effective mitigation and sequestration strategies, knowledge of the nature of $\mathrm{GHG}$ emissions from various crop production activities is required. Since crop enterprises may vary in terms of their GHG 
emission efficiency, such measures could focus on either improving resource use efficiency and/or product substitution as possible strategies for reducing GHG emissions.

Many studies in Canada and the U.S.A. have addressed issues surrounding GHG emissions. Addressing mitigation of GHG emissions is the starting point in many of these studies, where the best opportunities are investigated (Garnett [4]). Study of soil carbon sequestration has been addressed by Gregorich et al. [5], Curtin et al. [6], while Bergstrom et al. [7], Liang et al. [8], and Sainju et al. [9] have also reported the effect of tillage on soil carbon sequestration. Several studies (McGinn and Akinremi [10]; Gregorich et al. [11]; and Paul et al. [12]) have also reported GHG emissions in the context of crop rotations. Some studies have estimated livestock GHG emissions (see Vergé et al. [13]). However, these studies have not addressed the issue of relative contribution of various crops in different regions of Canada. Such information may be important for developing strategies for reducing GHG emissions.

The objective of this study was to estimate the regional GHG Emissions Intensity Coefficient (GHG-EIC) of various crops in Canada. Emphasis was placed on dryland production systems and on conventional tillage systems. Although irrigation production systems are also responsible for GHG emissions, they are relatively small in comparison to total production.

\section{Methods and material}

Within Canada, most crop production activities are localized in the Prairie Provinces (Manitoba, Saskatchewan, and Alberta) and Central Canada ( Ontario and Quebec). Together these two regions constitute 97.6\% of total cropped area of Canada. British Columbia and Atlantic Canada were, relatively speaking, minor players.

GHG emissions from dryland production systems in various regions are typically a result of two sets of factors: crop mix and technology of production. Although both of these factors need to be captured in a comparison of GHG-EIC, the latter is left for future research in this area. Thus, this study is limited to differences in GHG-EIC for various crops and major regions of agricultural production in Canada. This consideration was captured in the development of a model called the Greenhouse Gas Emissions Model (GHGEM), which was calibrated for the base year 2006 (Census of Agriculture in Canada year). The model was an update of the model described by Sobool and Kulshreshtha [14]. Results were aggregated at the provincial level. Although the GHGEM included both crop and livestock production activities, as well as dryland and irrigated method of crop production, in this study only dryland crop production activities are included.

GHG emissions from agriculture are generated in three ways: (1) Direct emissions from agricultural production related activities; (2) Indirect emissions through ecosystem level changes, and (3) Induced emissions, which are the economic activities resulting from the production of farm commodities. For example, in the production of wheat, use of fertilizer would be a source of direct 
emissions. It results in atmospheric deposition and leaching into groundwater, and which are classified as indirect emissions. Production of wheat requires manufacturing of fertilizer, which generates further emissions; in addition, this production is mostly exported to outside regions and has to be transported. These two sources are called induced emissions.

In order to estimate these three types of emissions, the GHGEM was designed in a modular fashion. Each module represents a set of related activities. Although soil carbon sequestration is an activity included in the model, since it is not crop specific, it has been shown as a separate activity. Various modules in the GHGEM are shown in table 1. The main source of data for emission factors was the IPCC Tier-1 methodology as described in Houghton et al. [15], supplemented with those from Olsen et al. [16] and Nyboer and Laurin [17].

Table 1: GHGEM modules and activities along with their association by type of gas.

\begin{tabular}{|c|c|c|c|c|}
\hline Module & Module Activity & $\mathrm{CO}_{2}$ & $\mathrm{CH}_{4}$ & $\mathrm{~N}_{2} \mathrm{O}$ \\
\hline \multirow{2}{*}{$\begin{array}{l}\text { Crop Production } \\
\text { Emissions Module }\end{array}$} & Crop Residues & & & $\mathrm{X}$ \\
\hline & Nitrogen Fertilizers & & & $\bar{X}$ \\
\hline $\begin{array}{c}\text { Energy Use Emissions } \\
\text { Sub-Module }\end{array}$ & Machinery Fuel Use & $\mathrm{X}$ & $\mathrm{X}$ & $\mathrm{X}$ \\
\hline \multirow{2}{*}{$\begin{array}{c}\text { On-Farm Transportation } \\
\& \text { Stationary Combustion } \\
\text { Emissions Module }\end{array}$} & On-Farm Transportation & $\mathrm{X}$ & $\mathrm{X}$ & $\mathrm{X}$ \\
\hline & Other On-Farm Fuel Use & $\mathrm{X}$ & $\mathrm{X}$ & $\bar{X}$ \\
\hline $\begin{array}{c}\text { Sub-total Direct GHG } \\
\text { Emissions }\end{array}$ & & $\mathrm{X}$ & $\mathrm{X}$ & $\mathrm{X}$ \\
\hline \multirow{2}{*}{$\begin{array}{c}\text { Indirect Emissions } \\
\text { Module }\end{array}$} & Atmospheric Deposition & & & $\mathrm{X}$ \\
\hline & Nitrogen Leaching & & & $\mathrm{X}$ \\
\hline \multicolumn{2}{|c|}{ Total Direct \& Indirect Production-Related Emissions } & $\mathrm{X}$ & $\mathrm{X}$ & $\bar{X}$ \\
\hline Farm Inputs & $\begin{array}{c}\text { Manufacturing, } \\
\text { Transportation and } \\
\text { Storage }\end{array}$ & $\mathrm{X}$ & $\mathrm{X}$ & $\mathrm{X}$ \\
\hline Off-farm Transportation & & $\mathrm{X}$ & $\mathrm{X}$ & $\mathrm{X}$ \\
\hline \multicolumn{2}{|c|}{ Total Agricultural GHG Emissions } & $\mathrm{X}$ & $\mathrm{X}$ & $\mathrm{X}$ \\
\hline
\end{tabular}

Direct crop-production-related emissions included those from crop production activities (such as decomposition of crop residues and application of nitrogenbased fertilizers), and use of fossil fuels for farm machinery and transportation. The On-Farm Transportation and Stationary Combustion Emissions Module was divided into two areas of fuel use, namely the consumption of fossil fuels related to the transport of the crops after harvest from the field to the bins and the energy requirements for all other activities (limited to those related to crop production, such as crop drying) on the farm Dyer et al. [18]. The Indirect Emissions Module contained emissions resulting from the application of nitrogen-based fertilizers that subsequently resulted in nitrogen being either volatized into the air or 
leached into the soil and subsequently into groundwater. The induced emissions contained two modules - Farm input manufacturing and off-farm transportation. All emissions were converted into $\mathrm{CO}_{2}$, and are not shown by individual gases. As noted above, crop production also leads to either soil carbon source or sequestration. However, these emissions could not be estimated for each crop and therefore, are not included in the total GHG emissions Dyer et al. [18]. H

Estimation of GHG emission intensity coefficients (GHG-EIC) was done for three Prairie Provinces (Manitoba, Saskatchewan and Alberta) in western Canada, and for Ontario and Quebec in eastern Canada. These were estimated using two criteria: on per unit of land (ha), and per tonne of production. In total, five crops (alfalfa, spring wheat, durum wheat, barley, and canola) in western Canada and four crops (alfalfa, wheat, corn for grain, and soybeans) in eastern Canada were included.

\section{Results and discussion}

\subsection{Distribution of greenhouse gas emissions from wheat production in Saskatchewan}

To illustrate the nature of GHG emissions from crop production, wheat in Saskatchewan was selected. Saskatchewan is a major contributor to wheat production in the Prairies. Composition of total GHG emitted ha ${ }^{-1}$ and on per tonne $\left(\mathrm{t}^{-1}\right)$ is shown in table 1. A distribution of these emissions is shown in figure 2 .

To produce wheat in Saskatchewan, a total of $530 \mathrm{~kg}$ of GHG ha ${ }^{-1}$ is released, of which the majority comes from fuel use and fertilizers. As shown in figure 2, these emissions are only $62 \%$ of the total emissions. After all wheat- production-

Table 2: The distribution of total $\mathrm{GHG}$ in $\mathrm{CO}_{2 \mathrm{e}}$ from spring wheat production in Saskatchewan on per ha and per tonne basis.

\begin{tabular}{|c|c|c|}
\hline Source & $\begin{array}{c}\text { Emissions } \\
\left(\mathrm{kg} \mathrm{ha}^{-1}\right)\end{array}$ & $\begin{array}{c}\text { Emissions } \\
\left(\mathrm{kg} \mathrm{t}^{-1}\right)\end{array}$ \\
\hline Fertilizer & 53.92 & 13.65 \\
\hline Other Crop Sources & 155.16 & 39.28 \\
\hline Fuel for farm machinery & 216.89 & 54.91 \\
\hline On-farm Transportation and other uses & 104.07 & 26.35 \\
\hline Total Farm Level Emissions & $\mathbf{5 3 0 . 0 3}$ & $\mathbf{1 3 4 . 1 8}$ \\
\hline $\begin{array}{c}\text { Indirect Emissions } \\
\text { Farm Input Production, Transportation, } \\
\text { Storage }\end{array}$ & 31.22 & 7.90 \\
\hline Off-farm Transportation & 41.79 & 64.54 \\
\hline $\begin{array}{c}\text { Total Emissions excl. Soil Organic } \\
\text { Matter }\end{array}$ & $\mathbf{8 5 7 . 9 6}$ & $\mathbf{2 1 7 . 2 0}$ \\
\hline
\end{tabular}




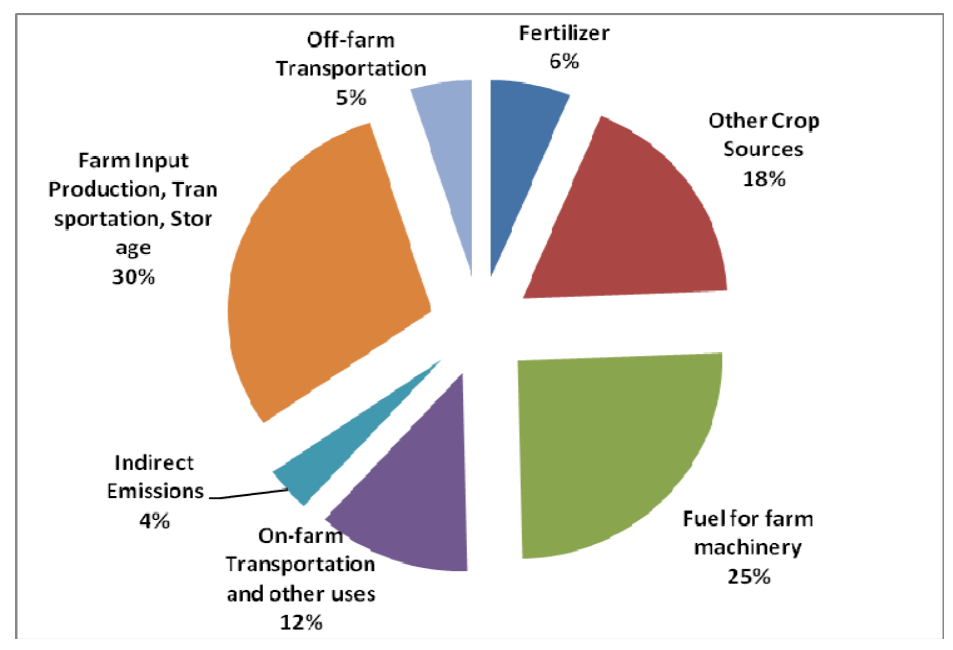

Figure 2: Distribution of total wheat-production-related GHG emissions.

related activities are accounted for, a hectare of wheat generates a total of $858 \mathrm{~kg}$ of $\mathrm{CO}_{2 \mathrm{e}} \mathrm{GHG}$ emissions. The remaining $38 \%$ are through activities beyond the farm level. These include manufacturing of farm input which contributes $30 \%$ to the total and the remaining through off-farm transportation activity.

The above set of estimates does not include the soil carbon sequestration potential of various crops. Part of the reason for this is that sequestration estimates in Canada are available only at a Census Agriculture Region (CAR) level and not by crops. Furthermore, carbon sequestration in soils changes from one time period to another, depending on cultural practices and soil characteristics. For these reasons, this estimate was excluded from the total.

\subsection{Estimated area-based GHG-EIC for crops in the Prairies}

As noted above, five crops were selected for the estimation of GHG-EICs in the Prairie Provinces. Results are shown in table 2. Both direct farm level emissions and total system (farm and beyond-farm activities) were included here. For alfalfa, GHG emissions from farm level activities ranged from 141 to $351 \mathrm{~kg}$ $\mathrm{ha}^{-1}$. One of the crops with the highest emissions level was durum wheat production in Saskatchewan, where 1.1 t of GHG are emitted from every hectare of durum wheat production.

Although all the estimates in table 2 are for crops grown using intensive (or conventional) tillage, provincial differences in GHG-EIC show variability caused by differences in soil type as well as cultural practices. For crops such as alfalfa and barley, Manitoba has a higher GHG-EIC than other provinces. Differences in fertilization and fuel use (resulting from the soil characteristics) may be partial answer to these differences. 
Table 3: Area-based greenhouse gas emission intensity $\left(\mathrm{CO}_{2 \mathrm{e}} \mathrm{kg} \mathrm{ha}{ }^{-1}\right)$ of crops in Prairie Provinces.

\begin{tabular}{|c|c|c|c|c|}
\hline Crop & Level & Alberta & Saskatchewan & Manitoba \\
\hline \multirow{2}{*}{ Alfalfa } & Direct Farm & 140.9 & 231.2 & 351.3 \\
\cline { 2 - 5 } & Total & 378.7 & 803.5 & 644.4 \\
\hline \multirow{2}{*}{$\begin{array}{c}\text { Spring } \\
\text { Wheat }\end{array}$} & Direct Farm & 530.0 & 701.1 & 642.6 \\
\cline { 2 - 5 } $\begin{array}{c}\text { Durum } \\
\text { wheat }\end{array}$ & Total & 858.0 & $1,179.6$ & 981.6 \\
\cline { 2 - 5 } & Direct Farm & 558.3 & $1,127.1$ & 742.0 \\
\hline \multirow{2}{*}{$\begin{array}{c}\text { Barley } \\
\text { (Feed) }\end{array}$} & Dotal & 885.2 & $1,837.0$ & $1,088.7$ \\
\hline \multirow{2}{*}{ Canola } & Dotal & 529.6 & 538.3 & 757.7 \\
\cline { 2 - 5 } & Direct Farm & 386.0 & 885.6 & $1,140.6$ \\
\cline { 2 - 5 } & Total & 744.7 & 720.8 & 645.6 \\
\hline
\end{tabular}

\subsection{Production based GHG-EIC for crops in Prairie provinces}

Comparison of area-based emissions may be misleading if yields of various crops are different across the three provinces Dyer et al. [18]. For this reason, area-based coefficients were converted to a per-tonne basis to take into account regional production efficiencies that may exist. Doing so allows for a regional comparison of intensity coefficients. While the area-based estimates may be significantly higher for one crop or region compared to another, the input requirements may result in an optimal yield for the specific crop or region. This optimal yield may help to overcome the high area-based intensity coefficient estimates, resulting in a production coefficient that is more efficient when compared to other regions where yields are relatively lower. However, climate plays an important role in determining yields, and this fact makes these coefficients vary over time. The results are shown in table 3.

When production efficiencies are captured, GHG-EICs show a different pattern across the Prairies. For example, for alfalfa production, Manitoba had the

Table 4: $\quad$ Production-based greenhouse gas emission intensity $\left(\mathrm{CO}_{2 \mathrm{e}} \mathrm{kg} \mathrm{t}^{-1}\right)$ of crops in Prairie Provinces, under intensive tillage system.

\begin{tabular}{|c|c|c|c|c|}
\hline Crop & Level & Alberta & Saskatchewan & Manitoba \\
\hline \multirow{2}{*}{ Alfalfa } & Direct Farm & 56.6 & 162.4 & 86.7 \\
\cline { 2 - 5 } & Total & 152.1 & 294.3 & 159.1 \\
\hline \multirow{2}{*}{$\begin{array}{c}\text { Spring } \\
\text { Wheat }\end{array}$} & Direct Farm & 134.2 & 214.0 & 241.6 \\
\cline { 2 - 5 } & Total & 217.2 & 358.5 & 369.0 \\
\hline \multirow{2}{*}{$\begin{array}{c}\text { Durum } \\
\text { wheat }\end{array}$} & Direct Farm & 126.3 & 272.3 & 175.8 \\
\cline { 2 - 5 } $\begin{array}{c}\text { Barley } \\
\text { (Feed) }\end{array}$ & Total & 200.3 & 443.7 & 258.0 \\
\cline { 2 - 5 } Canola & Direct Farm & 133.7 & 138.7 & 158.9 \\
\cline { 2 - 5 } & Total & 229.6 & 228.2 & 239.1 \\
\cline { 2 - 5 } & Total & 273.7 & 241.1 & 247.4 \\
\hline
\end{tabular}


highest area-based coefficients (table 3), but such is not the case when these are adjusted for higher yields in that province. To produce a tonne of alfalfa emits only $159 \mathrm{~kg}$ of GHG in Manitoba, as against $294 \mathrm{~kg}$ in Saskatchewan, when all crop-production-related activities are accounted for. Canola production seems to have a relatively higher GHG-EIC in all three provinces, compared to cereal crops. Most of the increase in emissions is a result of higher fuel use for this production.

\subsection{Crop production GHG-EIC for eastern Canada}

Although the crop mix in western Canada is not exactly comparable to that in eastern Canada, every attempt was made to select similar crops. Alfalfa, being a major source of forage, provided no problem. Wheat in Ontario could be considered similar to that in the western region. In eastern Canada, corn is used as a major feedgrain and is comparable to barley in western Canada. Canola is an oilseed crop and is similar to production of soybeans in eastern Canada. For these crops, GHG-EIC is presented in table 4.

Corn is an input-intensive crop, as the GHG-EIC shows. For just the farm level, every hectare of corn in Ontario produces $2.2 \mathrm{t}$ of GHGs in carbon dioxide equivalent. This is the highest GHG-EIC among all crops. These coefficients also show that crop production in Quebec is less GHG-emitting than in Ontario. These differences are a result of different cultural practices followed in the two provinces.

Table 5: Area and production based greenhouse gas emission intensity of crops in eastern Canada.

\begin{tabular}{|c|c|c|c|c|c|}
\hline \multirow{2}{*}{ Crop } & \multirow{2}{*}{ Level } & \multicolumn{2}{|c|}{ Ontario } & \multicolumn{2}{c|}{ Quebec } \\
\cline { 3 - 6 } & & $\mathrm{kg} \mathrm{ha}^{-1}$ & $\mathrm{~kg} \mathrm{t}^{-1}$ & $\mathrm{~kg} \mathrm{ha}^{-1}$ & $\mathrm{~kg} \mathrm{t}^{-1}$ \\
\hline \multirow{2}{*}{ Alfalfa } & Direct Farm & 563.8 & 79.8 & 484.7 & 86.4 \\
\cline { 2 - 6 } & Total & 957.3 & 135.6 & 669.0 & 119.3 \\
\hline \multirow{2}{*}{ Wheat } & Direct Farm & $1,240.5$ & 153.5 & $1,017.1$ & 174.5 \\
\cline { 2 - 6 } & Total & $1,770.5$ & 219.1 & $1,257.0$ & 215.6 \\
\hline \multirow{2}{*}{$\begin{array}{c}\text { Corn for } \\
\text { Grain }\end{array}$} & Direct Farm & $2,197.5$ & 147.5 & $1,872.4$ & 155.8 \\
\cline { 2 - 6 } & Total & $3,085.9$ & 207.1 & $2,271.0$ & 188.9 \\
\hline Soybean & Direct Farm & 630.8 & 241.7 & 622.1 & 249.9 \\
\cline { 2 - 6 } & Total & 839.7 & 321.7 & 731.1 & 294.6 \\
\hline
\end{tabular}

\subsection{Comparison of crop-production-related GHG-EIC between western and eastern Canadian provinces}

Comparison of selected crops for Saskatchewan and Ontario is shown in figure 2. In both regions, corn production is the highest GHG-emitting crop on a per ha basis, but not on the basis of its total production. 


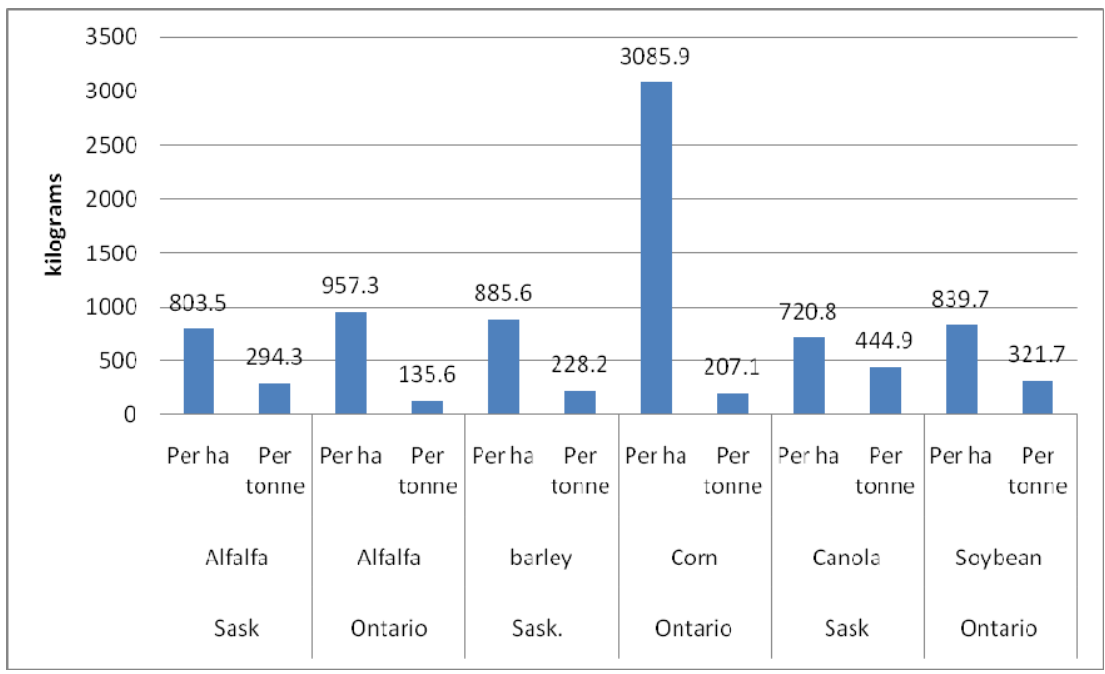

Figure 3: Comparison of GHG-EIC on area and production basis between Saskatchewan and Ontario, selected crops.

Both corn and alfalfa produce a higher yield per unit of land, and therefore, on a production basis, they are not as high a GHG emitter as barley. In general, on account of yield differences, Saskatchewan's GHG emissions rates are higher than those in Ontario.

The above analysis also shows that regional variation in the production-based GHG-EICs is less than that of the area-based estimates. One of the main reasons for this reduction is the differences in allocation of inputs, particularly fertilizer. The contribution level of the fertilizer related GHG-EIC to total GHG-EIC ranged from a high of $32 \%$ for Ontario corn production to a low of $14 \%$ for Saskatchewan barley production. The optimal level of fertilization is positively correlated to crop yield; thus, higher fertilization rates for various crops result in higher yields. The end result is that for various crop types, increasing the fertilization rate will increase crop yields by a greater amount, thus decreasing the GHG-EIC on a production basis relative to an area basis.

\section{Summary and implications}

This study has demonstrated a wide variability in the greenhouse gas emission intensity among regions and crops under dryland production. Such information needs to be taken into account in the formulation of regional agricultural GHG emission reduction measures. However, the picture of EICs changes whether one examines these emissions on the basis of area or production. When estimated on an area basis, the GHG-EICs in Central Canada are higher than those for the Prairie Provinces, but on a basis of tonnes of production, Ontario crop production is more GHG-friendly than that in the Prairies. 
Table 6: Estimated solid carbon sequestration potential in Prairies and central region of Canada.

\begin{tabular}{|c|c|c|c|}
\hline \multirow{2}{*}{ Region } & \multicolumn{3}{|c|}{ Amount in $\mathrm{kg} \mathrm{ha}^{-1}$} \\
\cline { 2 - 4 } & Source & Sink & Net amount \\
\hline Prairies & 15.35 & -99.10 & -83.75 \\
\hline Central Canada & 112.02 & 0 & 112.02 \\
\hline
\end{tabular}

Source: Sobool and Kulshreshtha [14].

These conclusions are based on a methodology where soil carbon sequestration is not taken into account. Regionally there are wide differences in the level of carbon that is sequestered on an annual basis, as shown in table 4.

For the Prairies, it is estimated that overall the region has a potential for sequestration at $83.75 \mathrm{~kg} \mathrm{ha}^{-1}$, but for Central Canada, crop production emits 112 $\mathrm{kg} \mathrm{ha}^{-1}$ over all CARs within these provinces. There is a significant intraregional variability in these estimates, since in the Prairie Provinces, some CARs emit $\mathrm{CO}_{2}$ whereas others provide sequestration. In the Central Canada no CAR does sequestering of $\mathrm{CO}_{2}$. If these estimates were to be included in the estimation of the GHG-EIC, crop production in the Prairies would be more GHG-emissionsfriendly that that in Central Canada.

Overall, while the absolute value of the GHG-EICs is an important factor in determination of overall damage to environment (through climate change), the regional and crop-specific comparisons also provide the greatest insight as to emission efficiencies. In addition, there is a large variability among crops and for the same crop among regions.

While certain regions or crop types may be a significant source of GHG emissions on an absolute scale, these values really do not provide any insights as to formulating GHG mitigation policies that are the most efficient. These emission coefficients should prove to be useful for developing an efficient GHGmitigation policy for agriculture (crop production), or at least allow for the priorizing of GHG-mitigation strategies based on region and crop types. One of the limitations of these results is the partial nature of estimation. For example, pasture and forages are typically associated with livestock production. Similarly, the rotation followed for various crops is also different from region to region. Further studies could focus on these issues related to GHG emissions from dryland production systems.

\section{Acknowledgements}

This research was financed by a research grant obtained from the BIOCAP Canada, Social Sciences and Humanities Research Council, and Agriculture and Agri-Food Canada (Strategic Policy Branch, \& Semi-arid Prairies Agricultural Research Center). 


\section{References}

[1] Environment Canada. Information on greenhouse gas sources and sinks: Data and reports. On-Line. http://www.ec.gc.ca/pdb/ghg/data_reports e.cfm. 2005.

[2] Environment Canada. National Inventory Report - Greenhouse Gas Sources and Sinks in Canada. Part I. Ottawa. 2010.

[3] Dyer, J.A. \& Desjardins, R.L., A review and evaluation of fossil energy and carbon dioxide emissions in Canadian agriculture. Journal of Sustainable Agriculture, 33(2), pp. 210-228, 2009.

[4] Garnett, T., Where are the best opportunities for reducing greenhouse gas emissions in the food system (including the food chain). Food Policy. 36, pp. 523-532, 2011.

[5] Gregorich, E., Rochette, P., VamdenBygaart, A. \& Angers, D., Greenhouse gas contributions of agricultural soils and potential mitigation practices in Eastern Canada. Soil and Tillage Research, 83(1), pp. 53-72, 2005.

[6] Curtin, D., Selles, F., Wang, H., Zentner, R. \& Campbell, C., Restoring organic matter in a cultivated, semiarid soil using crested wheatgrass. Can. J. Soil Sci., 80, pp. 429-435, 2000.

[7] Bergstrom, D., Monreal C. \& St. Jacques, E., Influence of tillage practice on carbon sequestration is scale dependent. Can. J. Soil Sci., 81, pp. 63-70, 2001.

[8] Liang, B., McConkey, B., Schoneau, J., Curtin, D., Campbell, C., Moulin, A., Lafond, G., Brandt S. \& Wang. H., Effect of tillage and crop rotations on the light fraction organic carbon and carbon mineralization in Chernozemic soils of Saskatchewan. Can. J. Soil Sci., 83, pp. 65-72, 2003.

[9] Sainju, U., Whitehead W. \& Singh, B., Cover crops and nitrogen fertilization effects on soil aggregation and carbon and nitrogen pools. Can. J. Soil Sci., 83, pp. 155-165, 2003.

[10] McGinn, S. \& Akinremi, O., Carbon dioxide balance of a crop-fallow rotation in western Canada. Can. J. Soil Sci., 81, pp. 121-127, 2001.

[11] Gregorich, E., Drury C. \& Baldock, J., Change in soil carbon under longterm maize in monoculture and legume-based rotation. Can. J. Soil Sci., 81, pp. 21-31, 2001.

[12] Paul, E., Collins, H. Paustian, K. Elliott, E. Prey, S. Juma, N. Janzen, H. Campbell, C. Zentner, R. Lafond G. \& A. Moulin, G., Management effects on the dynamics and storage rates of organic matter in the long-term crop rotations. Can. J. Soil Sci., 84, pp. 49-61, 2004.

[13] Verge, X., Dyer, J., Desjardins, R., \& Worth, D., Greenhouse gas emissions from the Canadian beef industry. Agricultural Systems, 98, pp. 126-134, 2008.

[14] Sobool, D. \& Kulshreshtha, S., Greenhouse gas emissions from Canadian agriculture model: Technical documentation. University of Saskatchewan, Saskatoon, SK., 2005.

[15] Houghton, J., Meira Filho, L., Lim, B., Treanton, K., Manaty, I., Bonduki, Y., Griggs, D. \& B. Callander, B., Intergovernmental Panel on Climate 
Change greenhouse gas inventory reporting instructions. Volumes 1-3. Bracknell. U.K., 1997.

[16] Olsen, K., Collas, P. Boileau, P., Blain, D., Ha, C., Henderson, L., Liang, C., McKibbon, S. \& Morel-a-l'Huissier L., Canada's greenhouse gas inventory. Environment Canada, Greenhouse Gas Division. Ottawa, ON., 2002.

[17] Nyboer, J. \& Laurin, A., Development of greenhouse gas intensity indicators for Canadian industry. Prepared for Environment Canada and Natural Resources Canada. Canadian Industrial Energy End-use Database and Analysis Centre. Simon Fraser University. Burnaby, B.C., 2002.

[18] Dyer, J.A., Vergé, X.P.C., Desjardins, R.L., Worth, D.E. \& McConkey, B.G., The impact of increased biodiesel production on the greenhouse gas emissions from field crops in Canada. Energy for Sus. Dev., 14(2), pp.73$82,2010$. 